\title{
An Initial Archaeological and Historical Assessment of Three Proposed Dam Sites in Gonzales and Kendall Counties, Texas
}

\author{
Thomas R. Hester \\ Center for Archaeological Research \\ Thomas C. Kelly \\ Center for Archaeological Research \\ Feris A. Bass Jr. \\ Center for Archaeological Research
}

Follow this and additional works at: https://scholarworks.sfasu.edu/ita

Part of the American Material Culture Commons, Archaeological Anthropology Commons, Environmental Studies Commons, Other American Studies Commons, Other Arts and Humanities Commons, Other History of Art, Architecture, and Archaeology Commons, and the United States History Commons

Tell us how this article helped you.

This Article is brought to you for free and open access by the Center for Regional Heritage Research at SFA ScholarWorks. It has been accepted for inclusion in Index of Texas Archaeology: Open Access Gray Literature from the Lone Star State by an authorized editor of SFA ScholarWorks. For more information, please contact cdsscholarworks@sfasu.edu. 


\section{An Initial Archaeological and Historical Assessment of Three Proposed Dam Sites in Gonzales and Kendall Counties, Texas}

\section{Creative Commons License}

\section{(c) (1) \&}

This work is licensed under a Creative Commons Attribution-NonCommercial 4.0 International License 
AN INITIAL ARCHAEOLOGICAL AND HISTORICAL ASSESSMENT

OF THREE PROPOSED DAM SITES IN

GONZALES AND KENDALL COUNTIES, TEXAS

Thomas R. Hester, Thomas C. Kelly, and Ferts A. Bass, Jr.

Center for Archaeological Research

The University of Texas at San Antonio

Regional Studies, No. 2

February, 1975 


\section{TABLE OF CONTENTS}

$\begin{array}{lc}\text { Introduction } & \text { Page } \\ \text { Historical Background } & 1 \\ \text { Archaeological Background } & 2 \\ \text { Archaeological Reconnaissance at the Three } & 5 \\ \quad \text { Reservoir Sites } & 7 \\ \text { Summary and Recommendations } & 27 \\ \text { Bibliography } & 30 \\ \text { Acknowledgements } & 32\end{array}$




\section{LIST OF FIGURES}

Figures

Page

1. Map of Gonzales Reservoir, Gonzales County, Texas

9

2. Chipped Stone Artifacts from Gonzales Reservoir II

3. Chipped Stone Artifacts from Gonzales Reservoir 13

4. Chipped Stone Artifacts from Gonzales Reservoir 17

5. Map of Dilworth Reservoir, Gonzales County, Texas 21

6. Map of Dam 7 Reservoir, KendalI County, Texas 25 
Under the terms of a contract with Ecology Audits, Inc., of Dallas, Texas, the Center for Archaeological Research at The University of Texas at San Antonio, carried out general archaeological and historical assessments in Gonzales and Kenda1I counties. The present report will form part of a larger document (to be submitted to the United States Bureau of Reclamation) dealing with proposed construction of the Gonzales and Dilworth dams (Gonzales County) and Dam 7 (Kendall County).

During the month of February, 1975, personnel of the Center for Archaeological Research compiled information on the archaeology and history of the areas of the three proposed dam sites. Emphasis was placed on an assessment of the archaeological resources and 5.5 days were devoted to fieid visits to the three proposed reservotr basins. The purpose of these field trips was not intensive survey, but rather a brief on-the-ground inspection of certain portions of these reservoirs, in order to provlde an initial, and quite general, assessment of the archaeological resources which might exist. Time was also devoted to a literature survey designed to provide historical summaries of the regions within which the reservoirs might be constructed. 
HISTORICAL BACKGROUND

Gonzales county

Gonzales County was settled by Green C. Dewitt in 1825

on a land grant from the Mexican Government. His grant provided for the settlement of 40 families. Dewitt sent James Kerr to establish a settlement in his grant in 1825, and the town of Gonzales was laid out in December of that year. The settlement was attacked by Indians in 1826 and the settlers fled.

The town of Gonzales was rebuilt in 1827 and the settlers slowly returned to the locality. The Indians remained troublesome and in 1831 the colonists were given a cannon with which to protect themselves. This cannon was to become a source of contention between the Mexican military and the settlers. This disagreement culminated in the Battle of Gonzales in 1835 in which Mexican troops, who had been sent to Gonzales to capture the cannon were repulsed. The Mexican attempt to punish the colonists for their resistance was one of the factors precipitating the Texas Revolution.

In the Texas Revolution, Gonzales was to play a key role. Sam Houston had planned to make the Guadalupe River at Gonzales the main line of resistance agalngt further Mexican incursions into Texas. But, because of the non-cooperation of Colonels Travis and Fannin, Houston was forced to withdraw toward the east after the fall of the Alamo in 1836. 
Gonzales County was formally organized in 1836 following the Texas declaration of independence. The county was one of the first localities in Texas to drive herds of cattle overland to Kansas in the $1870^{\prime} \mathrm{s}$. The northern portion of the county (In which the proposed Gonzales and Dilworth dams are located) was developed in the middle 1870 's with the building of the Galveston, Harrisburg, and San Antonio Railroad. It was at this time that the towns of Harwood and Waelder were established. The town of Dilworth was founded in 1885 when the San Antonio and Aransas Pass Railroad was built from Shiner to Lockhart. The town was named for G.N. Dilworth, a banker, who was instrumental In the building of the ratlroad.

Three historicaily important buildings in Gonzales County have been submitted to the National Register of Historic Places. These are: Gonzales County Courthouse, Kennard House, and Braches Home.

Kendale county

The first settlement in the territory that now comprises Kendal1 County was Tusculum in 1849. The settlers had been members of the Bettina Colony that had been established on the Llano River in 1847. These original settlers were scholars from the University of Heidelberg and Greissen who had organized themselves into a community, agreeing to share the work in their new agrarian home. However they were unable to make a success of the venture. Tusculum was founded by five of these dissatisfied settlers. But it lasted only until 1851 when the present town of Boerne, 
about two miles from the original site, was established. This town was named for Ludwig Boerne, a German poet and historian who was then a refugee in west Texas.

Sisterdale, approximately 15 miles north of Boerne, was also founded in 1847 by Nicholas Zink who was joined in 1848 and 1849 by a number of educated Germans who are reported to have had the finest schools in the state and set the pattern for later public education in Texas.

Bergheim, ten miles northeast of Boerne, was founded in 1887 by Andreas Engel and F. Hofheim. Early products of the community were cotton, charcoal, cedar, and corn.

Kenda11a, 25 miles northeast of Boerne was settled in 1885 as a ranching and farming community. 
ARCHAEOLOGICAL BACKGROUND

Gonzales county

Up to the time of our study, 146 archaeological sites had been recorded in Gonzales County. Of these, an intensive archaeological survey of the proposed Cuero I Reservoir accounted for 140 (Fox et al., 1974). The documented sites are primarily prehistoric occupation sites, spanning a period of 10,000 years, from PaleoIndian times to the Neo-American or late prehistoric era. One site dating from the Paleo-Indian period is $41 \mathrm{GZ} 1$, at which Folsom materials (dating from ca. 8800 B.C.) were found (cf. Hester 1974: Fig. 2, f-g). In addition to the prehistoric localities, 25 early 19 th century homesites have been recorded, and a number of other historic sites, including settlements, reputed historic Indian camps, battle sites, and early forts, are known to exist but have not as yet been recorded. Fort Wahl, dating from the Clvil War era, has recently been recorded by Orchard (ms.).

The number of sites located during the Cuero I Reservoir survey give an indication of the potential for future archaeological work in the county.

\section{Kendall county}

Although numerous sites in this county have been found by relic-collectors, scientific archaeology has been sporadic. As of January 1, 1975, a total of 23 archaeological sites had been recorded, of which approximately half were open occupation sites, and the other half, burned rock middens. Two rockshelters with 
occupational debris had also been documented. These sites reflect aboriginal occupation during the past 7,000 years, from the Archaic to the Neo-American periods. Many of the reported sites are located on terraces overlooking the major streams, or in the upper reaches of tributaries. Site records for these 23 sites are on file at the Texas Archeological Research Laboratory, Austin (see also Briggs, 1970).*

In February, 1975, the Center for Archaeological Research at The University of Texas at San Antonio, carried out an archaeological survey on Upper Cibolo Creek (and its tributaries) in western Kendall County (Bass and Hester, 1975). During the course of this survey, 33 prehistoric and historic sites were recognized. In the same area, Bill Fawcett has noted several additional prehistoric sites (notes on file, Center for Archaeological Research). Certainly only a small percentage of the historic and prehistoric archaeological resources in Kenda11 County have been properly documented. Sites are being rapidly destroyed through housing developments and relic-collector depredations. Many of the early 19th century historic sites, such as those of German settlers, have yet to be recorded.

* Since completion of this report, an archaeological survey in the Upper Cibolo Watershed of Kendall County has led to the documentation of 33 additional sites, dating mainly from the Archaic era. See F. A. Bass, Jr. and T. R. Hester (1975) "An Archaeological Survey of the Upper Cibolo Creek Watershed" Archaeological Survey Report, Center for Archaeological Research. The University of Texas at San Antonio 8. 
ARCHAEOLOGICAL RECONNAISSANCE AT THE THREE RESERVOIR SITES

Archaeological reconnaissance was carried out in the areas of the three proposed reservoirs. Sizable portions of each reservoir were inspected and selected areas were subjected to intensive survey. We must emphasize that our field work was a general nature and that it should not preclude required ful1-scale archaeological surveys of these proposed reservoir localities. Gonzales Reservoir

The proposed Gonzales dam is to be located across the San Marcos River in Gonzales County, $1.2 \mathrm{~km}$ north of the U.S. Highway $90 \mathrm{~A}$ bridge, and $3.2 \mathrm{~km}$ west of Gonzales (Fig.1). The maximum flood pool, at 314 feet m.s.1. would back water up the San Marcos River to the south edge of Luling and up Plum Creek to $1.5 \mathrm{~km}$ north of Interstate Highway 10 northeast of Luling.

The country is hilly on both sides of the San Marcos channel throughout this stretch of the river, and the river bottoms are either rich black gumbo soll or are swampy, depending on the nature of the drainage. These bottom lands were cultivated intensively thirty years ago, but now are mostly reverting to cattle pastures. Flora varies from impenetrable thickets of white brush, scrub oak and mesquite, to occasional stretches covered only with grass. The hills and ridges have thin soils of sandy red clay with outcroppings of Uvalde gravels. Some nice stands of pecan and walnut were observed.

During the course of reconnaissance in the Gonzales Dam area, 
Figure 1

Map of Gonzales Reservoir, Gonzales County, Texas.

Locations of archaeological sites are indicated.

\author{
Gonzales \# 1: $41 \mathrm{GZ} 147$ \\ Gonzales \# 2: $41 \mathrm{GZ} 148$ \\ Gonzales 非 3: $41 \mathrm{GZ} 149$ \\ Gonzales \# 4: $41 \mathrm{GZ} 2$ \\ Gonzales \# 5: 41 GZ 150
}




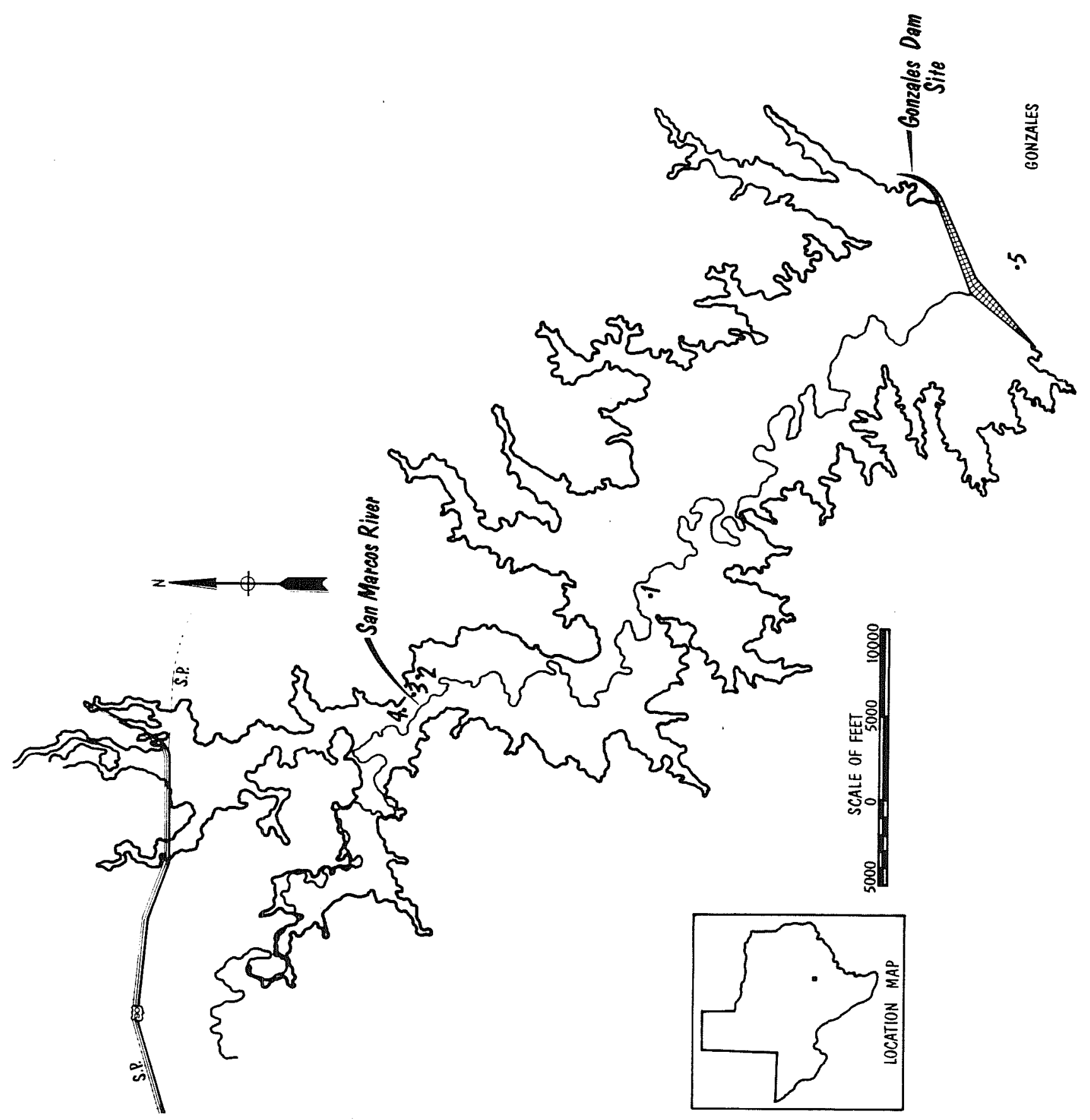




\section{Figure 2}

Chipped Stone Artifacts from Gonzales Reservoir.

a, Perdiz arrow point; b, $c$, thinned biface fragments;

d, e, unifacial tools (probably scrapers); f, cores.

A11 specimens are from Gonzales \# 1 (41 GZ 147). 

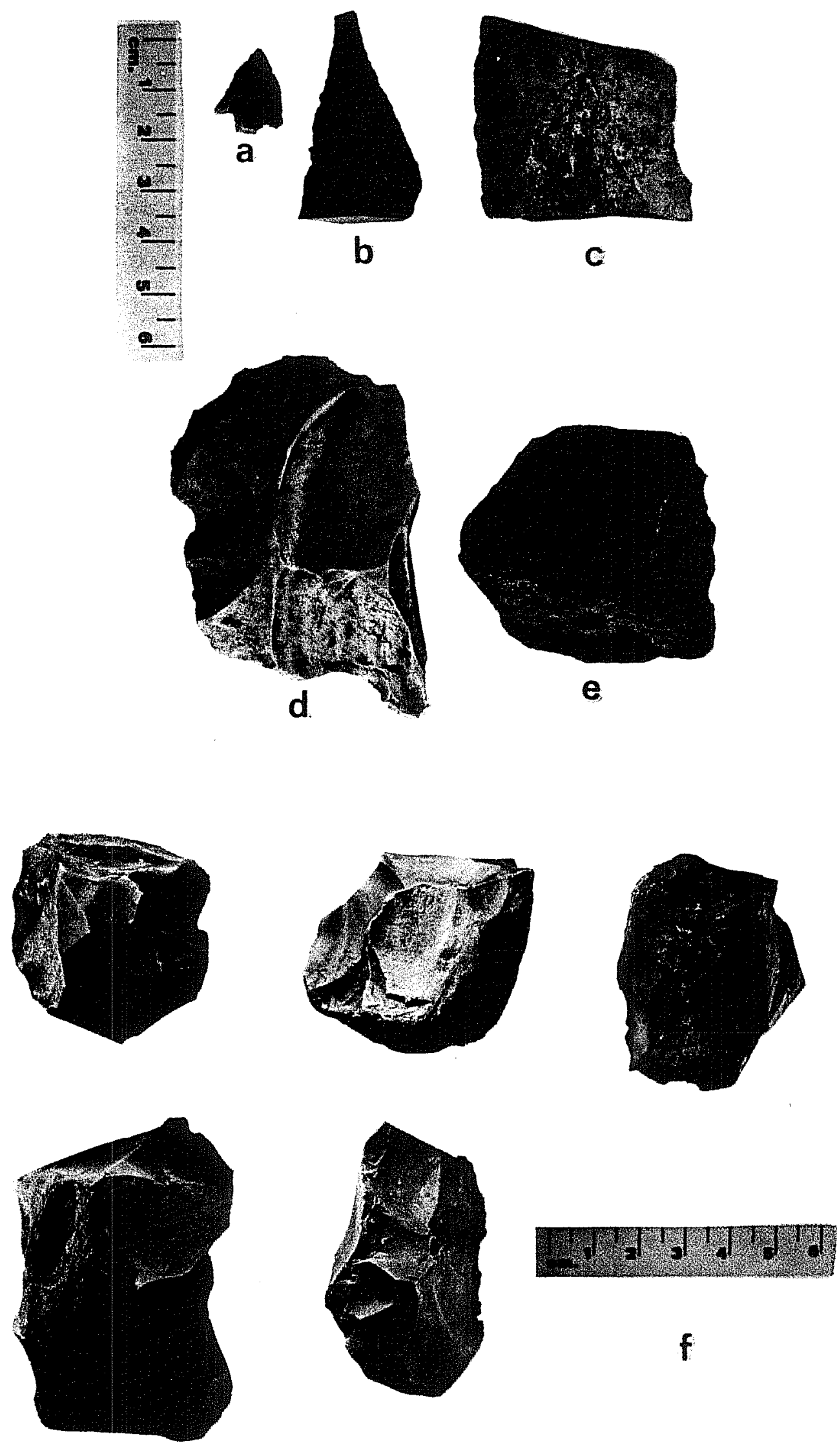

$f$ 
Figure 3

Chipped Stone Artifacts from Gonzales Reservair

$a$, Interior and cortex flakes; $b, b^{\prime}$, biface thinning flakes, resulting from tool manufacture ( $b$, ventral

face; $b^{\prime}$, dorsal face). All artifacts are from

Gonzales \# 1 (41 GZ 147). 

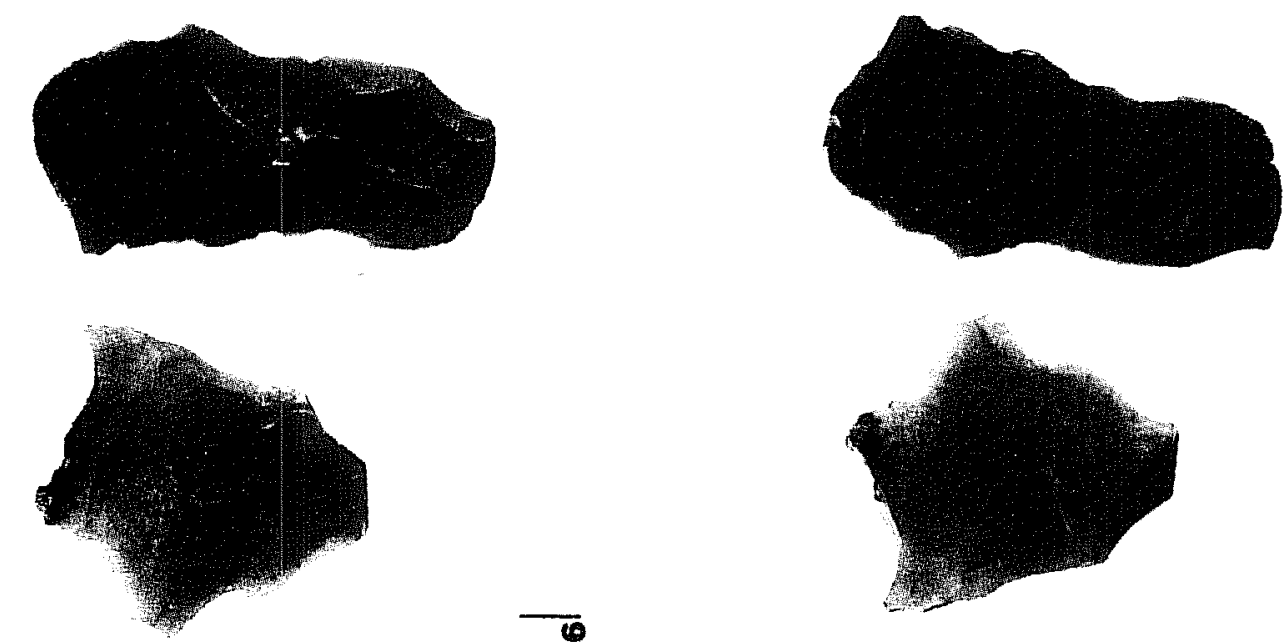

o
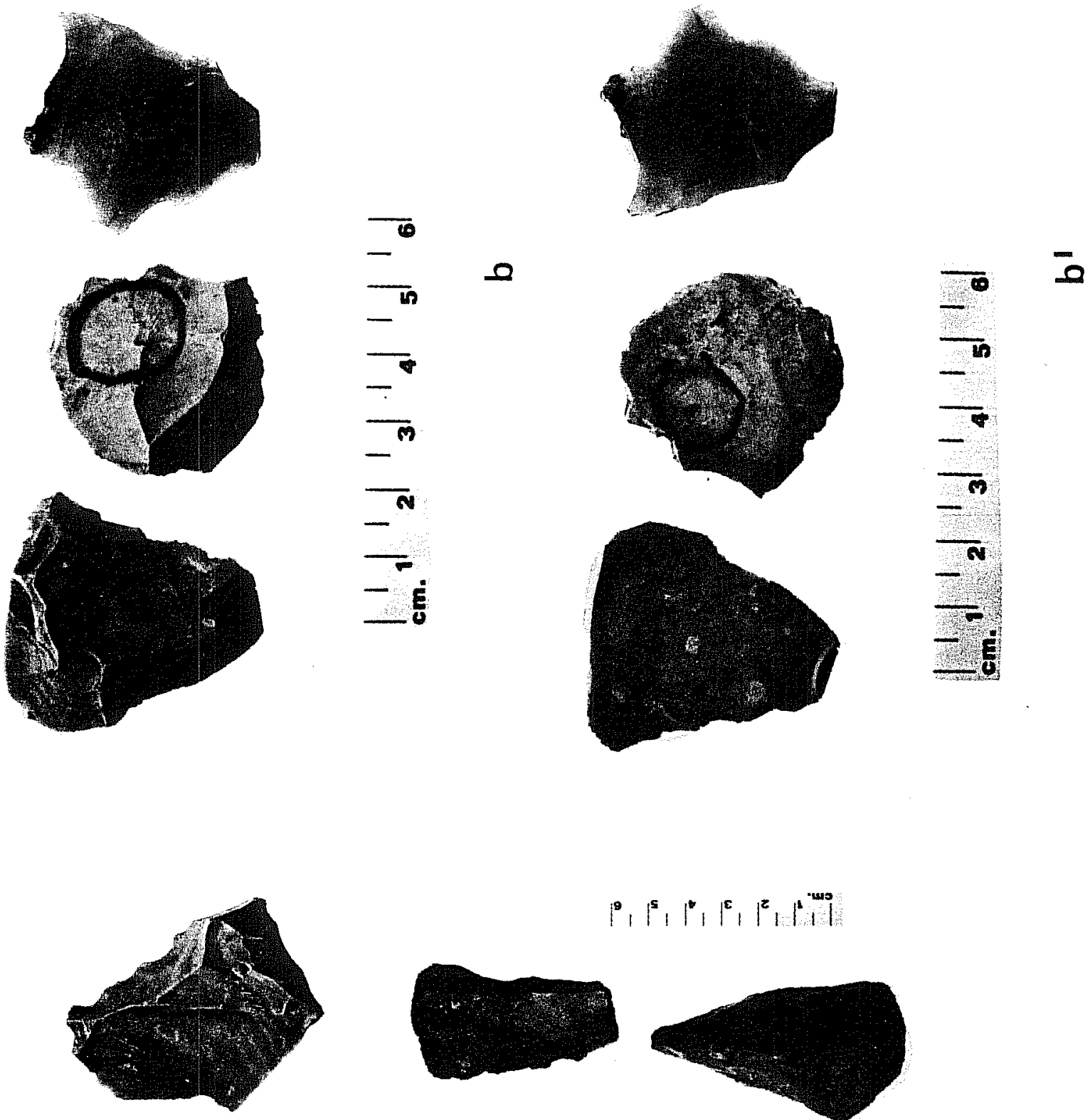

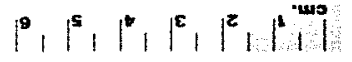
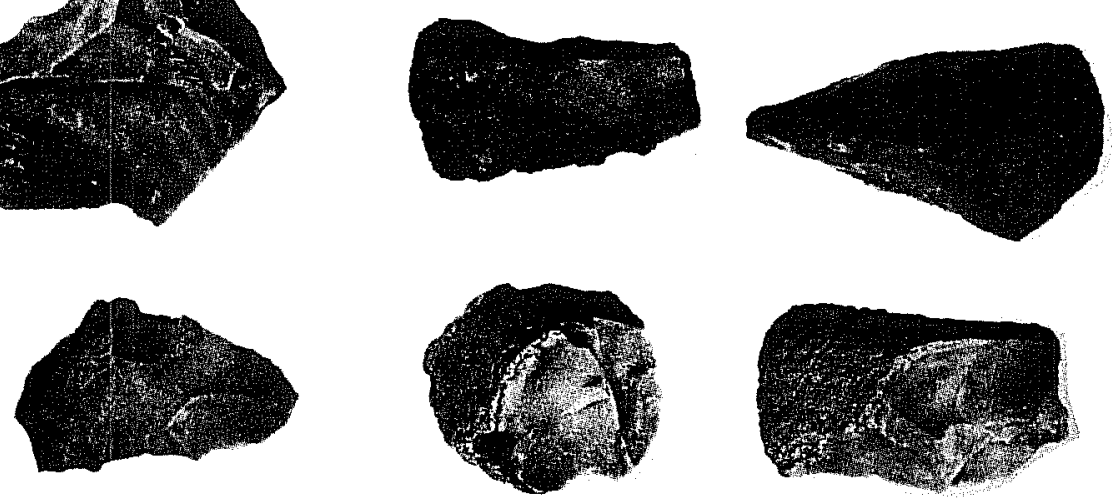

$\sigma$
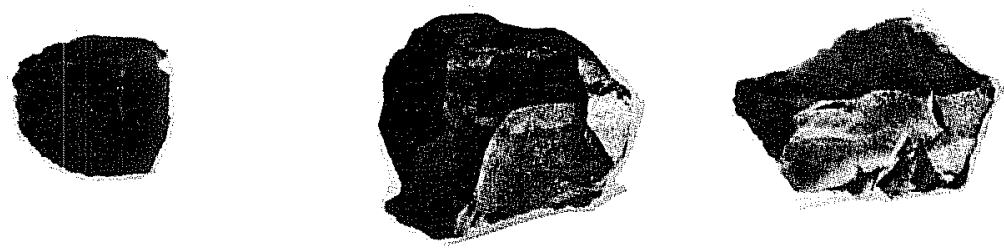
Five prehistoric archaeological sites were documented. These are described below.

Gonzales \#1 (41 GZ 147)

This site is situated on the west side of the San Marcos River just below Palmetto State Park. Ridge top erosion had exposed quantities of Uvalde gravels, and just below the ridge, an extensive Iithic workshop site was found.

Artifacts were confined to an area approximately $10 \mathrm{~m}$ in diameter, and a total. collection of all exposed materials was made. The artifacts include a Pedernales dart point, an unfinished dart point, 34 small cores, two large biface fragments, three notched flakes, four unifaces (probably scrapers) and 89 flakes. Some of the artifacts from this site are illustrated in Figs, 2 and 3 . About $50 \mathrm{~m}$ from the major concentration of. lithics, a Perdiz arrow point was found.

Additional intensive surface survey and exploratory excavations are recommended for this site.

Gonzales 非 (41 GZ 147)

The site is located along a gravel ridge $.7 \mathrm{~km}$ northeast of the San Marcos River. Erosion has exposed worked and unworked cobbles (Uvalde gravels) on the site surface. Flakes, cores, and one unifacial tool (possibly a scraper) were observed. The location of the site and the nature of the assemblage suggests that it functioned as a quarry-workshop. 
If an intensive survey of the reservoir is done in the future, this site should be re-examined.

Gonzales 非 (41 GZ 149)

This site is located on a sandy knoll about $.5 \mathrm{~km}$ eastnortheast of the San Marcos River, and was exposed through erosion in the bed of a road leading to an abandoned farmhouse. The site yielded a number of lithic specimens, including an end scraper made on a blade (Fig. 4), a core-scraper, two cores, hammerstone, and numerous flakes. All lithic materials were collected.

This knoll-top site probably served as an occupation locus. Additional occupation sites should be found on neighboring knolls overlooking the recent alluvial deposits and swampy areas found on the San Marcos floodplain to the south and west.

In addition to more extensive survey of this and nearby knolls, exploratory excavations should be carried out at Gonzales \#2.

Gonzales 非 (41 GZ 2)

E. B. Sayles originally reported this site in the 1930 's. It is situated on a grass covered knoll to the northeast of the confluence of Plum Creek and the San Marcos River. The site area is roughly circular, with a maximum diameter of $300 \mathrm{~m}$. Abundant lithic remains are present, including flakes, cores, blades, and unffactal and bifacial tools. Dlagnostic specimens collected during the survey include a Perdiz arrow point and a 
Figure 4

Chipped Stone Artifacts from Gonzales Reservair

a, end scraper, Gonzales \# 3 (41 GZ 149); b, Perdiz arrow point, Gonzales \# 4 (41 GZ 2); c, arrow point basal fragment, Gonzales \# 4 (41 GZ 2); Pedernales basal fragment, Gonzales \# 4 (4I GZ 2); e, large, stemmed dart point, Gonzales 5 (41 GZ 150. All artifacts are illustrated actual size. 

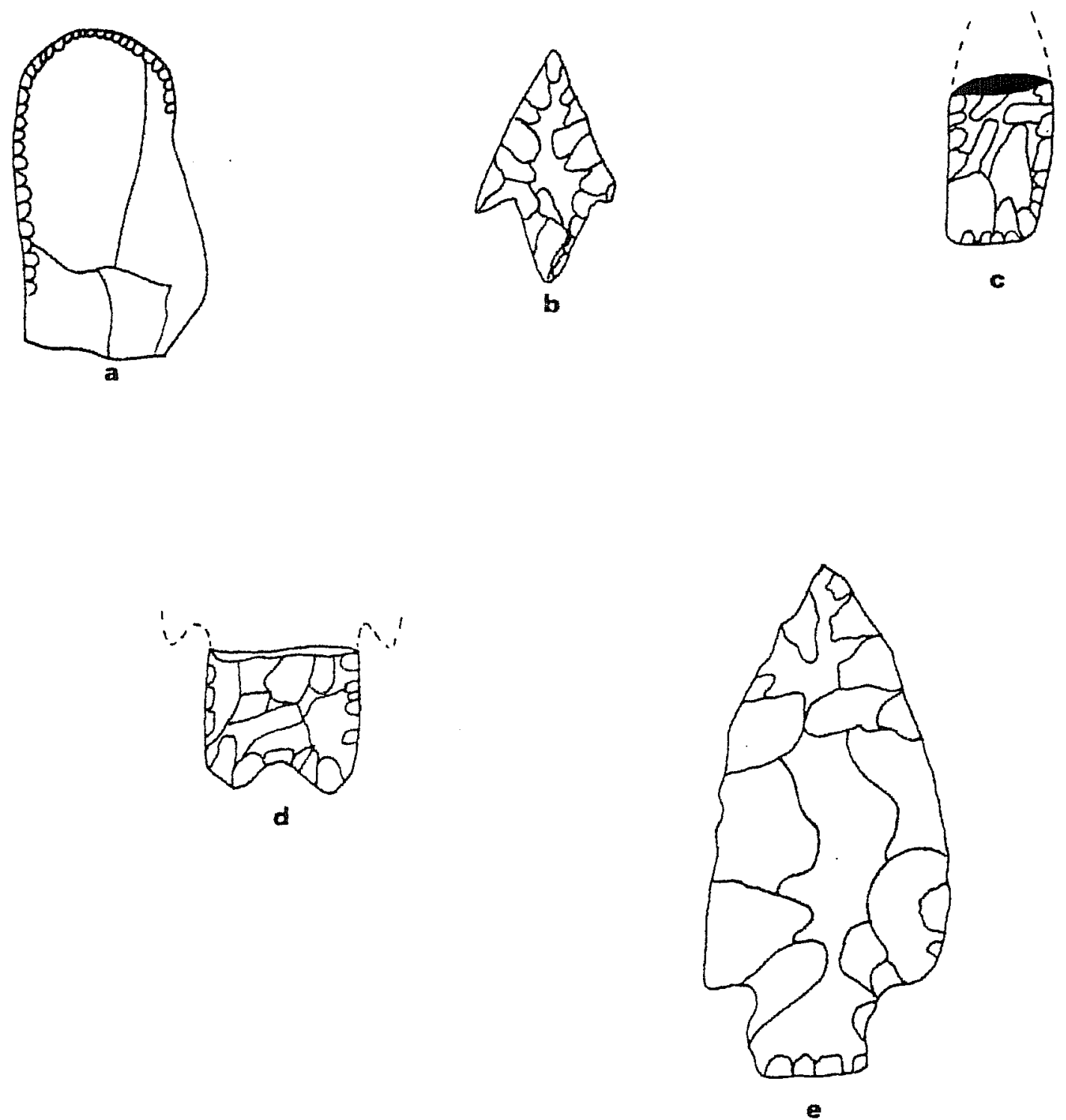
Pedernales dart point; a small lanceolate arrow point fragment was also found (see Fig. 4). Brief test cuts indicate the presence of buried deposits containing lithlcs, burned rock, charcoal, and quantities of land snalls.

Although the site has been cultivated in the past, deposits are probably sufficiently deep to warrant test excavations. Any future research in the Gonzales reservoir basin should include additional investigations at this site.

\section{Gonzales \#5 (41 GZ 150)}

The fifth site recorded during brief reconnaissance is located very near to the west end of the proposed dam, just above the San Marcos River. The site designation includes an eroded slope visited by the field team and an adjacent cultivated field from which Mr. E. V. Echols of Luling, Texas, has collected numerous Archaic dart polnts. Other local collectors have reportediy picked up materials in this field.

On an eroding sandy clay-loam slope at the north edge of the field, the field team observed lithic materfals in an area roughly 10 m In maximum diameter. The specimens include flakes, cores, core-choppers, unifaces, and a large, stemed Archaic dart point (Fig. 4).

Because of the wealth of archaeological materlals reported from the field and observed on the eroding north slope, it is recommended that test excavations be carried out as part of any future investigations related to the development of the Gonzales reservoir. In addition to fleld work, it might be profitable for 
future field workers to photograph and document known collections from the site. The UTSA field team was able to photograph portions of Mr. Echols' collection during the course of its reconnaissance.

Dilworth Reservair

The D1lworth Reservoir is planned to be constructed across Peach Creek $10 \mathrm{~km}$ north of its confluence with the Guadalupe River, approximately $13 \mathrm{~km}$ east of Gonzales, Texas. Denton Creek joins Peach Creek just above the proposed dam site near the former village of Dilworth.

Peach Creek flows from north to south, crossing Fayette and Bastrop Counties before entering Gonzales County. The stream gradient is slight and the valley is falrly flat and wide, resulting in the deposition of rich alluvium (a black gumbo soil). These soils were heavily cultivated in the past, but now are in cattle pastures. The uplands on both sides of the drainage are characterized by red sandy clay with frequent outcroppings of weathered conglomerate (cemented Uvalde gravels). The entire dralnage of Peach Creek and the surrounding hillsides are generally open with few trees, mostly varieties of oak and an occasional pecan and walnut. Some areas that were once cultivated now have a secondary growth of scrub oak, mesquite, white brush, and prickly pear. Archaeologically the area of the proposed Dilworth Reservoir Is an unknown, with no sites having been previously documented. Mr. Walter Mange of Gonzales has been collecting in Gonzales County for over 50 years, and knew of only one site in the Dilworth Reservolr basin. 
Figure 5

Map of Dilworth Reservoir, Gonzales County, Texas.

Location of archaeological site, Dilworth \# 1

(41 GZ 151), is indicated. 
Heavy vegetative cover, coupled with wet ground conditions, precluded any extensive on-the-ground inspection of the reservole basin. However, one archaeological site was documented and is briefly described below (see Fig. 5).

Dilworth 非 (41 GZ 151)

This is an uplands site, located on one of several eroded gravel hills approximately $1.6 \mathrm{~km}$ northwest of Peach Creek and $1.75 \mathrm{~km}$ north of FM Road 532. Eroded and weathered Uvalde gravel conglomerate had been used as a source of raw material by prehistoric groups. Cores, crude bifaces, and flakes are exposed in a farm roadbed, covering an area approximately $10 \times 30 \mathrm{~m}$. The function of the site appears to have been that of a quarry-workshop. In fact, many of the cobbles have only one flake removed, apparently the result of aboriginal "tests" of chert quality.

Future archaeological survey of the Dilworth Reservoir should Include another visit to this site, as well as the examination of the nearby gravel hills. Although a local relic collector knew of only one other site in the reservoir area, it seems certain that many more sites do exist given the presence of a permanent water source and the availability of other resources, such as chert outcrops. This prediction regarding the presence of additional archaeological sites is certainly supported by the findings of Fox et al. (1974: Fig, 1,a) on Peach Creek just downstream from the proposed Dilworth dam site. 
Dam 7 Reservair

The proposed Dam 7 is to be built across the Guadalupe River (Kendall County) along the Bergheim-Kendalia road, beginning $2.4 \mathrm{~km}$ north of Bergheim and extending north $8.7 \mathrm{~km}$. Water will be impounded under flood conditions to an elevation of $1257^{\prime}$ m.s.1. and will affect the Guadalupe channel as far upstream as the town of Sisterdale (FIg. 6).

Sabinas, Wasp, Spring, Goss, and Swede Creeks are the major drainages into the area. The uplands have thin soil and great expanses of exposed 11mestone. The creek and river bottoms have sandy loam soils. Cattle grazing is the primary industry within the area, followed by tourist and recreational areas such as the Alzafar Shrine camp. Only a few flelds are cultivated and those are in feed grasses such as coastal bermuda.

Two archaeological sites were documented in this brief reconnaissance but more are known to local collectors in the area and several have been previously recorded along the Guadalupe River, downstream from the proposed dam sites (Briggs, 1970).

Dam 7, Site 1 (41 KE 55)

This site is a burned rock midden cut in half by Spring Creek, on the Sam Woolford ranch (Fig.6). Spring Creek is a clear fast-flowing stream at this point, about $2 \mathrm{~km}$ from its confluence with the Guadalupe River. It borders a formerly cultivated fleld to the east, and its west bank rises up a fairly steep slope. A deposit ( $50 \mathrm{~cm}$ thick) of burned angular limestone and snail shells 
Figure 6

Map of Dam 7 Reservoir, Kendall County, Texas. Locations of archaeological sites are indicated.

Site \# 1: $41 \mathrm{KE} 55$

Site \# 2: 41 KE 56 


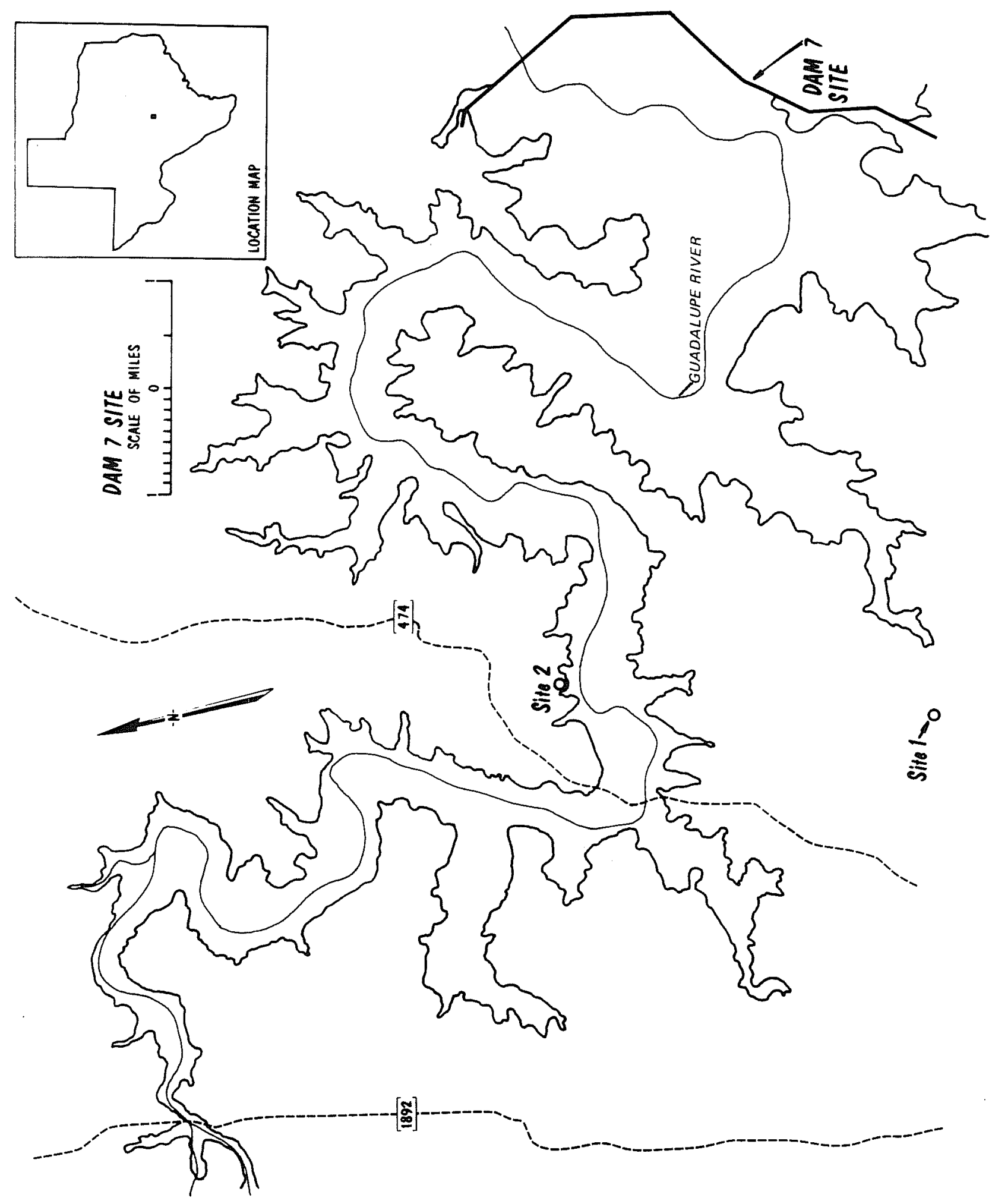


is exposed on both creek banks for $8 \mathrm{~m}$ along the creek. The midden 1 s buried by 1.5 m of overburden on the west bank and by $40 \mathrm{~cm}$ on the east bank.

The exposed sections of the burned rock midden were cleaned with a trowel and were photographed. No artifacts were found (In fact, no lithics were observed in these profiles) but the landowner has Pedernales and other Archaic dart points collected from the site.

Intensive archaeological investigations carried out prior to the construction of Dam 7 should include work at this site. It would probably produce information relevant to the burned rock midden problem in central Texas.

Dam 7, Site 2 (41 KE 56)

The second site is on the Perry Shankle Ranch, the first ranch northeast of Ammans Crossing on the Guadalupe River. The site is on a knoll rising above the floodplain of the Guadalupe River. Flint knapping debris, portions of dart points, scrapers, and cores were found eroding out of soil-filled rock crevices below the top of the knoll. A local collector who did contract work on the ranch some years ago has picked up a collection of diagnostic projectile points, including Pedernales, Montell, and Marcos dart points and a few Perdiz arrow points. Thus, occupation at $41 \mathrm{KE} 56$ apparently spans the period from Middle Archaic to late prehistoric times. 
SUMMARY AND RECOMMENDATIONS

In this report, we have reviewed the historical and archaeological backgrounds, and have presented new archaeological data derived from field visits, on the areas of three proposed Central Texas reservoirs. These projects, the Gonzales and Dilworth Reservoirs in Gonzales County, and Dam 7 in Kendall County, are all located in regions rich in archaeological and historical remains. The purpose of our brief field inspections was to sample some areas of the reservoirs. Because of the great areal extent of all three projects, and the necessity to secure individual landowner permissions for on-the-ground surveys, the allotted 5.5 days permitted only a glimpse of the archaeological resources. All of the newlyrecorded sites are prehistoric; however, the rich historical heritage of both counties indicates that significant historical ruins and structures may be expected to occur in the reservoir basins (cf. Fox et al.,1974 for the presence of such remains in Cuero I reservoir).

Our 11terature surveys and field inspections lead us to predict that several kinds of archaeological sites will be found in the reservoir basins. In the Dam 7 vicinity, burned rock middens, open occupation sites, and quarry-workshops will certainly be present. The burned rock middens and open occupation sites will be in topographic positions (floodplains, low terraces) which would be inundated upon completion of the dam. There is also the potential for the occurrence of rockshelters in the Dam 7 
area; Briggs (1970) provides a description of such sites found just downstream from the proposed site of Dam 7 .

In the two Gonzales County reservolrs, open occupation sites on the floodplains and terraces and open occupation and quarryworkshop sites on the terraces and hills overlooking the floodplain can be expected. Given the findings of Fox et al. (1974), the numbers of both historic and prehistoric sites will be substantial. These three proposed reservoirs are located in counties in which comparatively little systematic archaeological research has been done. Therefore, it becomes imperative that intensive archaeological-historical studies be carried out as an integral part of the planning and development of the reservoir projects. Such investigations are $I n$ most cases mandated by Federal and State legislation.

It will also be necessary to have the on-the-ground surveys sample the basins at different times of the year. In the summer and spring, heavy stands of grass and luxurtant vegetative growth will preclude any meaningful surface inspection. Additionally, the archaeological surveyors must cover very large areas in order to adequately sample the variety of cultural resources. Such Inspection will be hindered unless the planning and funding agencles secure easements to the affected properties. The land in all three reservolrs is divided among a great number of property owners, and the work of the survey team will be tremendously slowed (and thus made much more costly) unless such access is previously obtained. 
Furthermore, if obtaining permissions to survey becomes a part of the archaeologist's duties, this could, in some instances, put the team in the position of being caught in the middle of disputes between unhappy landowners and the planning agency. It is widely recognized that the neutrality of the archaeological and historical investigations is essential in providing factual and unbiased reports. In conclusion, we would like to emphasize the fact that all three reservoirs would substantially modify the stream drainages which they would Impound, and that this will cause widespread destruction of archaeological and historical resources. In order to predict the scope of mitigation activities that would be required by law, it is essential that planning and funding agencies authorize intensive surveys of these reservolr basins in their earliest stages of development. 


\section{BIBLIOGRAPHY}

Published and unpublished sources on the archaeology of Gonzales and Kendall Counties are listed below. These references cited in the text are indicated with an asterisk (*).

Gonzales county

Crawford, Daymond $D$. An Archeological Reconnaissance of Ecleto Creek Watershed South Central Texas. Texas Archeological Salvage Project Survey Repart 8. 1971.

* Fox, D. E., et a1.

Archeological Resources of the Proposed Cuero I Reservoir, Dewitt and Gonzales Counties, Texas. Texas Historical Commission and Texas Water Development Board, Archeological Survey Report 12. 1974.

* Hester, T. R.

On Fluted Points and South Texas Archeology. Texas Archeology 18 (2): $11-14.1974$.

Orchard C. D. Notes on Ft. Wahl, Gonzales, Texas. Notes on file at the Center for Archaeological Research. The University of Texas at San Antonio. 1974. Patterson, J. T.

The Corner-tang Flint Artifacts of Texas. The University of Texas Bulletin 3618. 1936. 
Patterson, J. T.

Boat-shaped Artifacts of the Gulf Southwest States. University

of Texas Bulletin 3732. 1937.

Patterson, J. T.

Supplementary Notes on the Corner-tang Artifact. University

of Texas Bulletin 3734: 27-39. 1937.

Kendall county

* Bass, F. A. Jr., and T. R. Hester

An Archaeological Survey of the Upper Cibolo Creek Watershed, Central Texas. Archaeological Survey Report 8, Center for Archaeological Research. The University of Texas at San Antonio. 1975.

* Briggs, A. K.

Preliminary Archaeological Survey of Study Area on the

Guadalupe River. Office of the State Archeologist, Special

Reports 13. 1970.

Enlow, Donald H. and T. N. Campbell

Some Paleo-Indian Projectile Points from the Southeastern

Periphery of the Great Plains. Panhandle-Plains Historical

Review 28: 29-37. 1955 .

Patterson, J. T.

The Corner-tang Flint Artifacts of Texas. The University of

Texas Bulletin 3618. 1936.

Wentworth, Irving $\mathrm{H}$.

A few Notes on Indian Mounds in Texas. Science 23 (595):

818-819. 1906 . 
32

ACKNOWLEDGEMENTS

We are grateful to Leo C. Fletcher and Nancy Y. Clayton (of the Center for Archaeological Research) for their aid during the archaeological reconnaissance. Additional assistance was rendered by C. D. Orchard of McQueeny, Texas and by Ruben Kuebal of Bourne, Texas. A number of landowners and county officials In Kendall and Gonzales Counties were of great help. Kathy MeCauley (Center for Archaeological Research) typed the report. 